\title{
Plasma membrane homing of tissue nonspecific alkaline phosphatase under the influence of 3-hydrogenkwadaphnin, an antiproliferative agent from Dendrostellera lessertii
}

\author{
Akram Sadeghirizi and Razieh Yazdanparast ${ }^{\bowtie}$ \\ Institute of Biochemistry and Biophysics, University of Tehran, Tehran, Iran \\ Received: 03 June, 2006; revised: 20 November, 2006; accepted: 24 April, 2007 \\ available on-line: 23 May, 2007
}

\begin{abstract}
Several mammalian enzymes are anchored to the outer surface of the plasma membrane by a covalently attached glycosylphosphatidylinositol (GPI) structure. These include acetylcholinesterase, alkaline phosphatase (AP) and 5'-nucleotidase among other enzymes. Recently, it has been reported that these membrane enzymes can be released into the serum by the GPI-dependent phospholipase $\mathrm{D}$ under various medical disturbances such as cancer and/or by chemical and physical manipulation of the biological systems. Treatment of MCF-7 cells with two consecutive effective concentrations of 3-hydrogenkwadaphnin (3-HK, $3 \mathrm{nM}$ ) for $48 \mathrm{~h}$ enhanced membrane AP activity by almost $330 \%$ along with a $40 \%$ reduction in the AP activity of the cell culture medium. In addition, our data indicate that $3-\mathrm{HK}$ is capable of inducing mainly the tissue-nonspecific alkaline phosphatase (TNAP) isoenzyme, along with enhancing its thermostability. These findings, besides establishing a correlation between the antiproliferative activity of 3-HK and the extent of plasma membrane AP activity, might assist in the development of new diagnostic tools for following cancer medical treatments.
\end{abstract}

Keywords: alkaline phosphatase, anti-proliferative, Dendrostellera lessertii

\section{INTRODUCTION}

Among the membrane-anchored proteins, the glycosylphosphatidylinositol (GPI)-containing are often involved in signal transduction and recognition processes (Low, 1989; Bortolato et al., 2002). The GPI anchor, linked to the C-terminal carboxyl group of the polypeptide chain, contains two acyl chains anchored into the lipid bilayer at the cell surface (Fergusson, 1999). These glycosylated enzymes have varying numbers of terminal sialic acid residues that effect their electrophoretic behavior (Eckerstall \& Nash, 1983). The GPI-protein can be released into the extracellular medium, forming a soluble form of the enzyme, by various physiological, chemical and physical stimuli.
Alkaline phosphatases (AP, orthophosphoric monoester phosphohydrolase, EC 3.1.3.1) are widely distributed in nature (Chang et al., 1994; Calhau et al., 2002). In human, at least four distinct AP isoenzymes have been identified using genetic and biochemical analyses (Tsai et al., 2000). The heat-stable isoenzyme from placenta (PAP) and the partially heat-stable isoenzyme from intestine (IAP) are tissue specific in terms of their expression. The heat-labile iso-zyme represents the liver-bone-kidney $(\mathrm{L} / \mathrm{B} / \mathrm{K}$ AP) or tissue nonspecific (TNAP) form. The fourth isoenzyme is also heat-stable and is present at low levels in germ cells (GCAP).

It has been previously reported that the plasma membrane-bound form of AP has significantly different kinetic and molecular properties

Corresponding author: R. Yazdanparast, Institute of Biochemistry and Biophysics, University of Tehran, P.O. Box 131451384, Tehran, Iran; tel: (98 21) 66956 976; fax: (98 21) 66404 680; e-mail: yazdan@ibb.ut.ac.ir

Abbreviations: AP, alkaline phosphatase; BCIP, 5-bromo-3-indolyl phosphate; Dex, dexamethasone; FBS, fetal bovine serum; GCAP, germ cells AP; GPI, glycosylphosphatidylinositol; 3-HK, 3-hydrogenkwadaphnin; IAP, intestine AP; LAP, liver AP; L/B/K AP, liver-bone-kidney AP; PAP, placenta AP; PBS, phosphate-buffered saline; pNPP, $p$-nitrophenylphosphate; $\mathrm{RA}$, retinoic acid; TNAP, tissue-nonspecific AP. 
compared to the soluble form of the enzyme. The membrane-bound form of AP is mostly believed to be tetrameric (Chan \& Stinser, 1986) and this may account for the differences in its enzymatic properties. It is suggested that alkaline phosphatase probably carries out its physiological and biochemical roles as an integral membrane protein (Chan \& Stinser, 1986). Ectopic expression of AP has been associated with a variety of human cancers. The aberrant expression of AP genes in cancer cells has led to the suggestion that AP isoenzymes may be involved in tumor development (Tsai et al., 2000).

It has been shown that AP genes can be modulated in a number of cell types by different agents such as glucocorticoids, progesterone, estradiol as well as retinoic acid (RA), an active metabolite of vitamin A (Ng et al., 1989; Lorenzo et al., 1991; Scheibe et al., 1991). These agents with significant proven roles in the regulation of diverse cellular processes such as proliferation and differentiation (Buzzard et al., 2003) mediate their function through binding to their corresponding receptors. The ligand binding to the receptors is followed by accumulation of the ligand-receptor complexes in the affected cells. The ligand-receptor complexes finally interact, as activated transcriptional factors, with specific DNA sequences located adjacent to the target gene(s) (Chang et al., 1994). Studying the regulation of the affected AP genes may disclose the mechanism of aberrant expression of these isoenzymes and their roles in cellular functions such as proliferation and differentiation.

We have previously shown that a crude extract of Dendrostellera lessertii and one of its active components, 3-hydrogenkwadaphnin, at safe doses, are capable of reducing the proliferation rates of various leukemia cell lines (mainly K562), arresting the cells at G1/S phase of the cycle and finally leading to apoptosis (Yazdanparast \& Sadeghi, 2004). The level of membrane AP of the treated cells was enormously enhanced while the level of the soluble form of the enzyme was decreased (although to a much lesser extent) compared to control cells (Sadeghi \& Yazdanparast, 2003). These observations, besides showing the anti-proliferative activity of $D$. lessertii extract, clearly question the involvement of AP isoenzymes in cell proliferation. Regarding this possibility, in this investigation the correlation between the antiproliferative activity of 3-hydrogenkwadaphnin and plasma membrane homing of AP isoenzymes in MCF-7 cells were evaluated and compared to the effects obtained following treatment of the cells with RA and dexamethasone (Dex) with established effects on alkaline phosphatase activity (Chang et al., 1994).

\section{MATERIALS AND METHODS}

Materials. Cell culture medium (RPMI 1640), fetal bovine serum (FBS) and penicillin-streptomycin were purchased from Gibco BRL (Life Technologies, Paisley, Scotland). The cell culture Petri dishes were obtained from Nunc (Denmark). Cell lines were obtained from the Pasteur Institute of Iran (Tehran). The AP substrate, p-nitrophenyl phosphate, was from Merck (Germany). Human placental AP, bovine intestinal and kidney AP (all in the form of lyophilized powder), Dex and RA were obtained from Sigma-Aldrich (St. Louis, MO, USA). Nitroblue tetrazolium/5-bromo-4-chloro-3-indolyl-phosphate (NBT/BCIP, Sigma, St. Louis, MO, USA) was used for detection of AP catalytic activity in electrophoretic gels.

Plant material. Aerial sections of D. lessertii were collected from suburbs of the central province of Iran at the end of spring. A herbarium voucher specimen was deposited at the Science Department of Tehran University. The plant material was dried, far from direct sunlight. The dried leaves were powdered and kept in a closed container in the cold room. The plant powder $(50 \mathrm{~g})$ was extracted three times with a mixture of methanol and water $(1: 1, \mathrm{v} /$ $v)$. The combined alcoholic extract was concentrated under reduced pressure to $50 \mathrm{ml}$. The purification and characterization of the active component was achieved as previously reported (Sadeghi \& Yazdanparast, 2005).

Cell culture. MCF-7 cells were cultured in RPMI 1640 medium supplemented with FBS (10\%, $\mathrm{v} / \mathrm{v})$, streptomycin $(100 \mu \mathrm{g} / \mathrm{ml})$, penicillin $(100 \mathrm{U} / \mathrm{ml})$ (Yoshida et al., 1996). The cells, $1 \times 10^{6}$, were seeded in triplicate into culture dishes and incubated at $37^{\circ} \mathrm{C}$ in an incubator with $5 \% \mathrm{CO}_{2}$. After $24 \mathrm{~h}$, the drug at various concentrations $(0,2.4,2.6,2.8,3$ and $3.2 \mathrm{nM}$ ) was given to the cells once a day and for 2 consecutive days. For the preparation of the drug stock solution, the purified compound was dissolved first in $10 \mu \mathrm{l}$ of dimethyl sulfoxide and the volume was adjusted to $1 \mathrm{ml}$ using cell culture medium. The cell viability was assessed by trypan blue exclusion test (Gorman et al., 1996) $48 \mathrm{~h}$ after treatment.

Extraction of alkaline phosphatase. The enzyme crude extract was prepared following the method of Chang et al. (1994). Briefly, the cells were washed twice with PBS and harvested by scraping with a rubber policeman into the resuspension buffer $\left(20 \mathrm{mM}\right.$ Tris/ $\mathrm{HCl}, 1.0 \mathrm{mM} \mathrm{MgCl}{ }_{2}, 150 \mathrm{mM} \mathrm{NaCl}$, $\mathrm{pH}$ 8.0). The cells were solubilized by adding Triton X-100 to a final concentration of $1 \%$. The cell-free supernatant was obtained by centrifugation at $12000 \times g$ for $15 \mathrm{~min}$.

Determination of AP activity. The AP activity was measured using $5 \mathrm{mM} p$-nitrophenyl phos- 
phate in bicarbonate buffer $\left(50 \mathrm{mM} \mathrm{HCO}_{3}^{-}, 0.5 \mathrm{mM}\right.$ $\mathrm{MgCl}_{2}$, pH 10.0) (Koyama et al., 1986). The reaction mixture was incubated at $37^{\circ} \mathrm{C}$ for $3 \mathrm{~h}$. The reaction was stopped by adding $1 \mathrm{ml}$ of $0.4 \mathrm{M} \mathrm{NaOH}$ to $2 \mathrm{ml}$ of the reaction mixture. Alkaline phosphatase activity was expressed as micromoles of $p$-nitrophenol produced per minute.

Native polyacrylamide gel electrophoresis. Electrophoresis was performed at room temperature with an $8 \%$ resolving acrylamide in $1.5 \mathrm{mM}$ Tris/ $\mathrm{HCl}, \mathrm{pH}$ 8.8. The $5 \%$ stacking gel was prepared in $1.0 \mathrm{mM}$ Tris/ $\mathrm{HCl} \mathrm{pH}$ 6.8. Enzyme samples in $50 \mathrm{mM}$ Tris/ $\mathrm{HCl}$ (pH 8.5) containing $0.1 \mathrm{mM} \mathrm{MgCl}{ }_{2}, 0.1 \mathrm{mM}$ $\mathrm{ZnCl}_{2}$ and $50 \mathrm{mM}$ Chaps were loaded onto the gel. The gel $(8 \times 10 \mathrm{~cm})$ was run at $20 \mathrm{~mA}$. The AP activity was visualized using $5 \mathrm{mg} / \mathrm{ml}$ solution of 5-bromo-3-indolyl phosphate, $p$-toluidine salt (BCIP) in $100 \mathrm{mM}$ Tris/ $\mathrm{HCl}, \mathrm{pH}$ 9.5, containing $5 \mathrm{mM} \mathrm{MgCl}{ }_{2}$ and $100 \mathrm{mM} \mathrm{NaCl}$ in the presence of NBT (Wong \& Low, 19992; Sambrook et al., 2001). The reaction was stopped at appropriate time using $20 \mathrm{mM}$ Tris/ $\mathrm{HCl}$, pH 2.9 containing $1.0 \mathrm{mM} \mathrm{CaCl}_{2}$.

Studies on inhibition of alkaline phosphatase activity. MCF-7 cells were incubated in the absence (control) or presence of Dex $\left(10^{-7} \mathrm{M}\right)$, RA $\left(10^{-6} \mathrm{M}\right)$, Dex plus RA or 3-HK $(3 \mathrm{nM})$ for 48 h. Crude cell extracts along with AP from human placenta (PAP), bovine intestine (IAP) or bovine liver (LAP) were assayed for enzyme activity, as described in the methods section. The AP residual activies of the samples $(20 \mu \mathrm{l})$ were determined, in duplicate, in the presence of several inhibitors of alkaline phosphatase isoenzymes namely L-Leu, L-Phe and L-homoarginine and EDTA. Each inhibitor was added to the standard assay mixture. The final concentration was $5 \mathrm{mM}$ for the amino acids, and 0.1 $\mathrm{mM}$ for EDTA. The varing concentrations of each inhibitor were prepared in the appropriate buffer from $100 \mathrm{mM}$ stock solutions. Tris/ $\mathrm{HCl}(100 \mathrm{mM}$, $\mathrm{pH}$ 8) was used for EDTA and bicarbonate buffer (50 $\mathrm{mM} \mathrm{HCO}_{3}^{-}, 0.5 \mathrm{mM} \mathrm{MgCl}_{2}$, $\mathrm{pH} 10.0$ ) for L-homoarginine inhibition studies. In the case of L-Phe, 1.0 M diethanolamine, $\mathrm{pH} 9.0$ and for L-Leu, $1 \mathrm{M}$ diethanolamine $\mathrm{pH} 10.3$ were used because these amino acids could not be dissolved in bicarbonate buffer (Hoylaerts et al., 1992). The inhibitor solutions $(1.0 \mathrm{ml})$ were added to the samples followed by incubation of the mixtures at room temperature for 10 min prior to the addition of $50 \mu \mathrm{l}$ of substrate ( $p$-nitrophenyl phosphate, pNPP) solution to a final concentration of $5 \mathrm{mM}$. Hydrolysis of pNPP catalysed by $\mathrm{AP}$ was performed for $3 \mathrm{~h}$ at $37^{\circ} \mathrm{C}$ and stopped with $1 \mathrm{ml}$ of $0.4 \mathrm{M} \mathrm{NaOH}$ to $2 \mathrm{ml}$ of the reaction mixture and the absorbance of the yellow $p$-nitrophenolate ion was measured at $405 \mathrm{~nm}$. The percentage of the residual activities was calculated against non-inhibited samples.
Heat inactivation. Aliquots of each sample $(20 \mu \mathrm{l})$ were heat-treated at $56^{\circ} \mathrm{C}$ for different time intervals. After heating, the samples were cooled quickly on ice and the residual activities were assayed at $37^{\circ} \mathrm{C}$, as above.

\section{RESULTS AND DISCUSSION}

Based on our previous investigation, K562 cells were found to be the most responsive cells to D. lessertii crude extract and 3-HK, compared to CCRF-CEM, HL-60 and Wehi-164 cells (Yazdanparast et al., 2003). The $\mathrm{IC}_{50}$ for the crude extract was established to be $0.36,0.42,0.40$ and $0.42 \mathrm{mg} / \mathrm{ml}$ for K562, CCRF-CEM, HL-60 and Wehi-164 cells, respectively. Similarly, the $\mathrm{IC}_{50}$ for 3-HK was established to be 3.5, 12, 15, $12 \mathrm{nM}$ for K562, CCRF-CEM, HL-60 and Wehi-164 cells, respectively. Under identical experimental conditions, the $\mathrm{IC}_{50}$ for MCF-7 cells was found to be around $0.13 \mathrm{mg}$ of the plant leaves powder per $\mathrm{ml}$ of the cell culture medium and around 3 $\mathrm{nM}$ using 3-HK. Regarding these results, the following investigation with MCF-7 cells was done at $\mathrm{IC}_{50}$ and/or sub-IC ${ }_{50}$ doses of 3-HK.

The effect of 3-HK on the growth pattern of MCF-7 cells was evaluated after 24 and $48 \mathrm{~h}$ exposure to various concentrations of the drug. Figure $1 \mathrm{~A}$ shows the number of viable cells, estimated by trypan blue exclusion test, after a single dose treatment with variable concentration of the drug. As shown, the number of cells continued to decrease at various time and drug concentrations. In addition to cell viability, 3-HK also affected the morphology of the treated cells compared to untreated control samples. As shown in Fig. 1B the untreated MCF-7 cells (Fig. 1B, a) mainly spread with polygonal morphology. However, the drug-treated cells after $24 \mathrm{~h}$ (Fig. 1B, b) or $48 \mathrm{~h}$ (Fig. 1B, c) of exposure showed extensive rounding. These data clearly indicate that 3-HK is capable of modulating cell-to-cell communications probably through modification of some plasma membrane constituents.

One of the cell surface constituents under the influence of $D$. lessertii is AP, according to our previous observations using different cancer cell lines (Sadeghi \& Yazdanparast, 2003). Our investigation with MCF-7 cells confirmed that upon treatments of the cells with two consecutive safe doses of $3-\mathrm{HK}$, the alkaline phosphatase activity of the cell culture media decreased by $40 \%$, while the total AP activity and the protein content of the solubilized membrane of the treated cells increased by $230 \%$ and $60 \%$, respectively (Fig. 2). The enhanced AP localization in the plasma membrane of the treated cells was also evident from the electrophoretic analyses of the samples. As 
A)

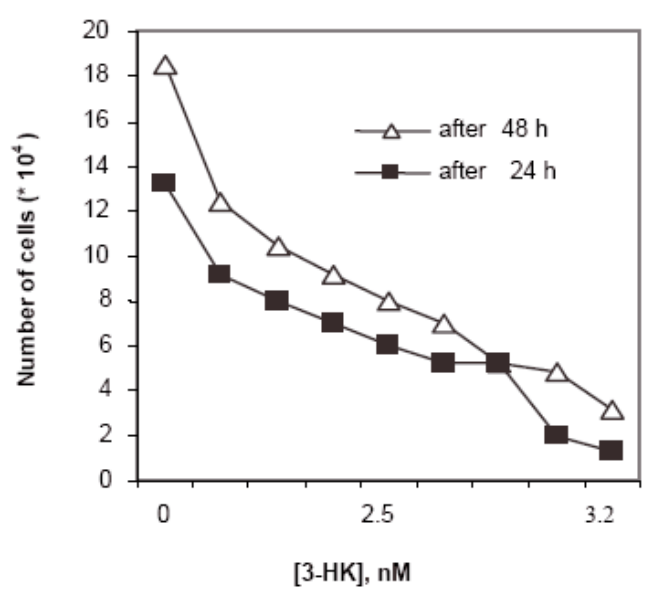

B)

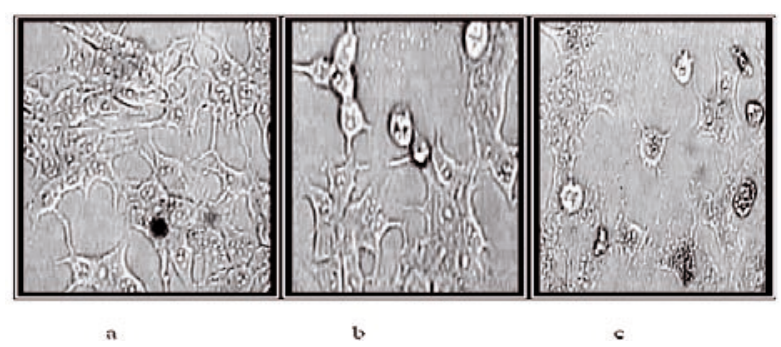

Figure 1. The effect of 3-HK at various concentration on cell viability and morphology.

The human MCF-7 cells were treated with two different concentrations of 3-HK. Number of cells (A) was counted using a hemocytometer after $24 \mathrm{~h}(\boldsymbol{\square})$ and $48 \mathrm{~h}(\Delta)$. The morphology of the cells (B) was analyzed using a light microscope after $24 \mathrm{~h} \mathrm{(b)}$ and $48 \mathrm{~h}$ (c) of treatment with a single dose of 3-HK ( $3 \mathrm{nM}$ ) compared to untreated cells (a). The results in A represent those of a single typical experiment.

shown in Fig. 3, the AP band of the treated cells is stronger than the AP band of the control sample. However, this difference in AP protein content is not comparable to the changes in the extracellular and intracellular AP activities shown in Fig. 2. Regarding the fact that 3-HK did not show any measurable direct effect on the activity of purified $\mathrm{AP}$, the results presented in Fig. 3 probably indicate that enhanced localization of AP molecules in the plasma membrane results in the enormous activity increase and this may result from the association of individual dimeric forms of the enzyme into multimeric forms. This conclusion is in full agreement with the literature data concerning the multimeric form of the plasma membrane alkaline phosphatase compared to its soluble form, which is a dimer (Nowrouzi \& Yazdanparast, 2005). It has been shown that the membrane form of AP, due to its polymeric form, has a higher molecular mass compared to molecular mass of the soluble

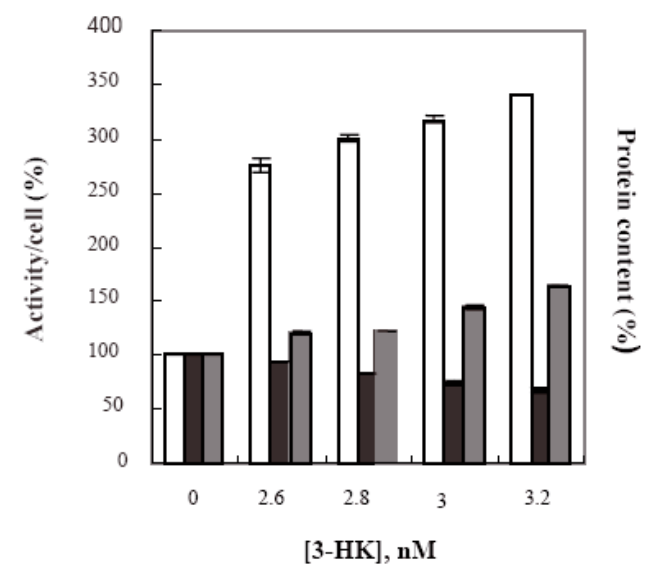

Figure 2. The effects of 3-HK on AP distribution. MCF-7 cells $\left(1.5 \times 10^{5}\right)$ were cultured in triplicate and treated with two consecutive doses of $3-\mathrm{HK}$ at various doses. After $48 \mathrm{~h}$, the cell culture media and the corresponding cells were collected and the AP activities in cell culture media ( $\square$ ) and plasma membrane ( $\square$ ) were measured according to procedure presented in the methods section. The protein content of the cell membrane fraction (回) was also measured. All data represent the mean of triplicate measurements \pm S.D.

dimeric form of the enzyme. Our data presented in Fig. 3 clearly indicate that the cell membrane AP of the treated MCF-7 cells has a higher molecular mass compared to the AP present in the concentrated cell culture medium.

Regarding the significant effect of 3-HK on the induction and localization of $\mathrm{AP}$, we were next interested to find out which isoenzyme(s) of AP are induced by $3-\mathrm{HK}$, using thermostability criteria and sensitivity to known isoenzymes specific AP inhibitors. These criteria could be used as diagnostic tools for following the medical treatment of specific or general cancer cases. In that regard, we first evaluated the effect of $3-\mathrm{HK}$ on total AP induction in MCF-7 cells in comparison to retinoic acid (RA) and dexamethason (Dex) effects. The data presented in Fig. 4 demonstrate that the AP activity in untreated control sample is relatively low. However, 3-HK, similarly to RA and Dex, markedly enhanced the activity of the cell membrane AP in a dose-dependent manner.

According to the observation by Chang et al. (1994), RA treatment of MCF-7 cells leads mainly to inductive expression of the heat-labile TNAP isoenzyme by a factor of 13.6. This is in contrast to the 0.5 -fold reduction of the partially heat-stable IAP isoenzyme in the same cells by RA treatment. Using specific AP inhibitors, it became evident that 3-HK exerts almost similar effects on MCF-7 cells with respect to AP isoenzyme induction as RA. As shown in Table 1, the AP isoenzymes in the drug-treated MCF-7 cells behave mostly like the heat-labile TNAP 
Table 1. Effects of specific inhibitors on MCF-7 AP activity.

MCF-7 cells were incubated in the absence (control) or presence of Dex $\left(10^{-7} \mathrm{M}\right), \mathrm{RA}\left(10^{-6} \mathrm{M}\right)$, Dex plus RA or 3-HK $(3 \mathrm{nM})$ for $48 \mathrm{~h}$. Crude cell extracts along with AP from human placenta (PAP), bovine intestine (IAP) and bovine liver (LAP) were assayed for enzyme activity, as described in the methods section. Each inhibitor was added to the standard assay mixture. The final concentration was of $5 \mathrm{mM}$ for L-Leu, L-Phe and L-homoarginine $0.1 \mathrm{mM}$ for EDTA. The data represents the average of triplicate measurements \pm S.D.

\begin{tabular}{|c|c|c|c|c|c|c|c|c|}
\hline \multicolumn{9}{|c|}{ MCF-7 AP activity (\% of control) } \\
\hline Inhibitors & Control & RA & Dex & RA+Dex & 3-HK & PAP & IAP & LAP \\
\hline EDTA & $7 \pm 1$ & $3 \pm 1$ & $10 \pm 3$ & $6 \pm 2$ & $6 \pm 1$ & $72 \pm 8$ & $12 \pm 1$ & $5 \pm 2$ \\
\hline L-Leu & $77 \pm 5$ & $72 \pm 2$ & $72 \pm 2$ & $72 \pm 3$ & $70 \pm 3$ & $21 \pm 4$ & $76 \pm 5$ & $72 \pm 5$ \\
\hline L-Phe & $83 \pm 6$ & $90 \pm 5$ & $79 \pm 4$ & $85 \pm 6$ & $83 \pm 5$ & $55 \pm 3$ & $71 \pm 2$ & $88 \pm 9$ \\
\hline L-Homoarginine & $66 \pm 4$ & $25 \pm 3$ & $72 \pm 5$ & $29 \pm 3$ & $30 \pm 3$ & $84 \pm 8$ & $86 \pm 14$ & $23 \pm 2$ \\
\hline
\end{tabular}

and the partially heat-stable IAP isoenzymes. The induced isoenzymes, like the TNAP and IAP forms, were resistant to $\mathrm{L}$-Leu and L-Phe but sensitive to EDTA and showed differential sensitivity to L-homoarginine, which is a specific inhibitor of TNAP. As it is evident from Table 1, RA- and (RA+Dex)induced isoenzymes showed higher sensitivity to Lhomoarginine compared to Dex-induced isoenzymes as was also reported by Chang et al. (1994).

The new anticancer drug 3-HK exerted similar effects on AP isoenzyme induction as did RA (Table $1)$. The higher induction level of the TNAP isoenzyme in MCF-7 cells relative to other forms of the enzyme upon treatment with RA and 3-HK was further confirmed by evaluating the thermostability of the induced isoenzymes. As shown in Fig. 5, the AP activity response of the control cell lysate at $56^{\circ} \mathrm{C}$ for various treatment times has a biphasic pattern indicating the presence of at least two different isoen-

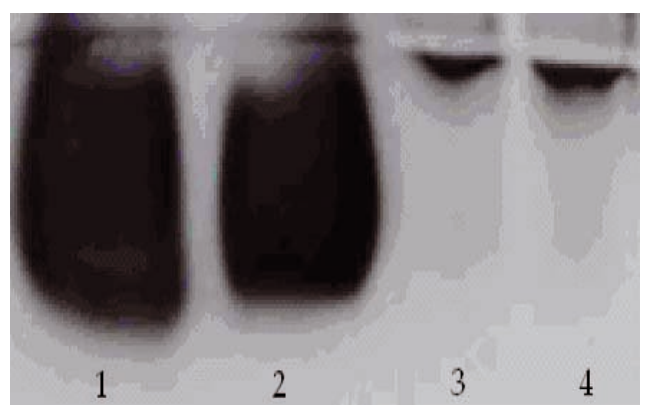

Figure 3. Alkaline phosphatase activity stain of MCF-7 cells before and after treatment with $3-\mathrm{HK}$.

MCF-7 cells $\left(1 \times 10^{4}\right)$ were cultured in 24-well culture plates for $24 \mathrm{~h}$. The cells were then treated with two consecutive doses of 3 -HK $(3 \mathrm{nM})$ for $48 \mathrm{~h}$. The cells were harvested, washed with PBS and AP was extracted from the cell membrane and electrophoresed as described in the methods section. The activity bands were visualized using NBT/BCIP. Lanes 1 and 2 correspond to AP activities in the concentrated cell culture medium, and lanes 3 and 4 represent the corresponding AP activities in MCF-7 cells before and after 3-HK treatments, respectively. zymes in the cell supernatant, one heat-labile and the other relatively more heat-stable. As it is evident from Fig. 5, the plant extract treatment of MCF-7 cells increased the left-hand side of the graph corresponding to the heat-labile isoform, TNAP, compared to the right hand side of the graph which represents the more heat-stable isoenzyme believed to be the IAP form (Fig. 5). Using the same approach as that used by Chang et al. (1994), the induction efficiency (or induction fold) of $3-\mathrm{HK}$ at a concentration of $3 \mathrm{nM}$ was determined to be 13.7 and 0.6 for the TNAP and IAP isoenzymes, respectively. These results are comparable to the induction efficiency of RA on TNAP (13.6) and IAP (0.5) reported by Cha et al. (1994).

The induction of AP by RA, Dex and 3-HK (Fig. 3) correlates well with the growth inhibition pattern of MCF-7 cells under the influence of these three agents. Our results are consistent with studies about the correlation of enhanced cell membrane AP activity and decreased cell proliferation of HeLa S3

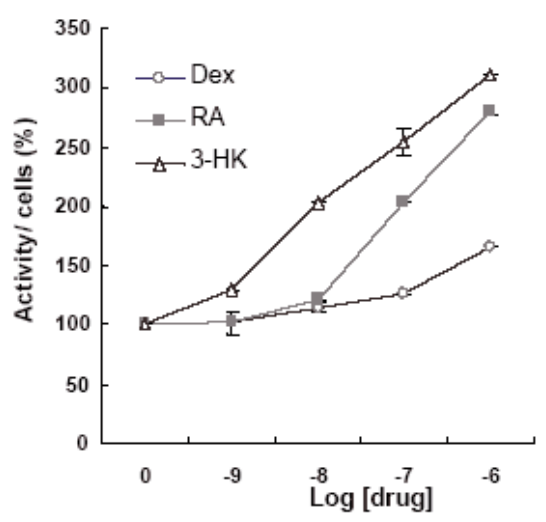

Figure 4. Effects of 3-HK, Dex and RA on cell membrane AP activity in MCF-7 cells.

Cells $\left(1 \times 10^{4}\right)$ were cultured in 24 -well culture plates for $24 \mathrm{~h}$ then exposed to various concentrations of 3-HK, Dex and RA for $48 \mathrm{~h}$. The cells were then collected, washed with PBS, the enzyme crude extract was prepared from the cell membranes and the enzyme activities were determined as described in the methods section. All data represent the mean of triplicate measurements \pm S.D. 


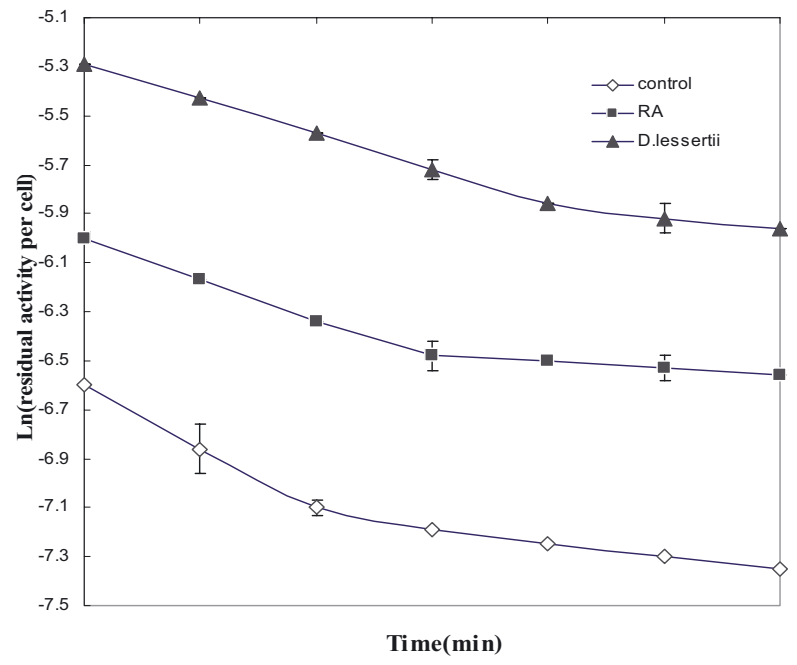

Figure 5. Effect of 3-HK on heat inactivation pattern of MCF-7 alkaline phosphatase.

Cells were incubated in the absence or presence of $3-\mathrm{HK}$ ( $3 \mathrm{nM}$ ) for $48 \mathrm{~h}$. Cell free extracts were prepared from both the control and treated cells. The thermostability of AP of each sample at $56^{\circ} \mathrm{C}$ was determined by incubating the cell extract in a constant-temperature water bath. Aliquot enzyme samples were withdrawn at indicated time intervals and assayed for the enzyme activities.

cells (Telfer \& Green, 1993). Further work is required to explore the mechanism of this correlation.

In conclusion, our findings demonstrated that 3-HK is capable of inducing AP expression and localizing the enzyme to its native place, the plasma membrane. This effects, among others, apparently bring about cell surface structural alterations, which effect cell-to-cell and cell-to-matrix communications. These alterations could be responsible for the anti-proliferative and anti-tumor activity of the new drug. Further works is in progress to explore the molecular mechanism of 3-hydrogenkwadaphnin.

\section{Acknowledgements}

The authors would like to thank the Research Council of the University of Tehran for providing the financial support of this investigation.

\section{REFERENCES}

Buzzard JJ, Wreford NG, Morrison JR (2003) Thyroid hormone, retinoic acid, and testosterone suppress proliferation and induce markers of differentiation in cultured rat sertoil cells. Endocrinology 144: 3722-3731.

Bortolato M, Besson F, Roux B (2002) An infrared study of the thermal and $\mathrm{pH}$ stabilities of the GPI-alkaline phosphatase from bovine intestine. Biochem Biophys Res Commun 292: 874-879.

Calhau C, Martel F, Hipolito-Reis C, Azevedo I (2000) Effect of P-glycoprotein modulators on alkaline phos- phatase activity in cultured rat hepatocytes. Cell Physiol Biochem 10: 195-202.

Chan JRA, Stinsor RA (1986) Dephosphorylation of phosphoproteins of human liver plasma membrane by endogenous and purified liver alkaline phosphatase. $J$ Biol Chem 261: 7635-7639.

Chang TC, Wang JK, Hung MW, Chiao CH, Tsai LC, Chang GG (1994) Regulation of the expression of alkaline phosphatase in a human breast cancer cell line. Biochem J 303: 199-205.

Eckerstall PP, Nash AS (1983) Isoenzymes of canine plasma alkaline phosphatase: An investigation using isoelectric focusing and related to diagnosis. Res Vet Sci 34: 310-314.

Fergusson MAJ (1999) The structure biosynthesis and functions of glycosylphosphatidyl-inositol anchors and the contributions of trypanosome research. J Cell Sci 112: 2799-2809.

Gorman A, McCarthy J, Finucane D, Reville W, Gotter T (1996) Morphologica assessment of apoptosis. In Techniques in Apoptosis. A user's Guide (Gotter TG, Martin ST, eds) pp 6-7, Protland Press Ltd, London.

Hoylaerts MF, Manes T, Millan JL (1992) Molecular mechanism of uncompetitive inhibition of human placental and germ-cell alkaline phosphatase. Biochem J 286: 23-30.

Koyama I, Sakagishi Y, Komoda T (1986) Different lectin affinities in rat alkaline phosphatase isozymes: multiple forms of the iso-zyme isolated by heterogeneities of sugar moieties. J Chromatogr 374: 51-59.

Lorenzo DD, Albertini A, Zava D (1991) Progesterone regulation of alkaline phosphatase in the human breast cancer cell line T47D. Cancer Res 51: 4470-4475.

Low MG (1989) The glycosyl-phosphatidylinositol anchor of membrane proteins. Biochem Biophys Acta 988: 427454.

Mianabadi M, Yazdanparast R (2004) The effect of Gnidilatimonoein from Daphne mucronata, on the adhesive property of human platelets. Iranian Biomed J 8: 143147.

Ng KW, Manji SS, Young MF, Findlay DM (1989) Opposing influences of glucocorticoid and retinoic acid on transcriptional control in preosteoblasts. Mol Endocrinal 3: 2079-2085.

Nowrouzi A, Yadanparast R (2005) Alkaline phosphatase retained in HepG2 hepatocarcinoma cells vs. alkaline phosphatase released to culture medium: Difference of aberrant glycosylation. Biochem Biophys Res Commun 303: 400-409.

Sadeghi H, Yazdanparast R (2003) Effect of Dendrostellera lessertii on the intracellular alkaline phosphatase activity of four human cancer cell lines. J Ethnopharm 86: $11-14$.

Sadeghi H, Yazdanparast R (2005) Isolation and structure elucidation of a new potent antineoplastic diterpene from Dendrostellera lessertii. Am J Chinese Med 33: 1-7.

Sambrook J, Russel D (2001) Molecular Cloning, A Laboratory Handbook, 3rd edn, Cold Spring Harbor Laboratory Press, New York.

Scheibe RJ, Moeller-Runge I, Muller WH (1991) Retinoic acid induces the expression of alkaline phosphatase in P19 teratocarcinoma cells. J Biol Chem 266: 2130021305.

Telfer JF, Green CD (1993) Placental alkaline phosphatase activity is inversely related to cell growth rate in HeLa S3 cervical cancer cells. FEBS Lett 329: 238-244.

Tsai LC, Hung MW, Chen VHSu, Chang GG, Ghang TC (2000) Expression and regulation of alkaline phos- 
phatase in human breast cancer MCF-7 cells. Eur J Biochem 267: 1330-1339.

Wong YW, Low MG (1992) Phospholipase resistance of the glycosylphosphatidylinositol membrane anchor on human alkaline phosphatase. Clin Chem 38: 2517-2525.

Yazdanparast R, Sadeghi H (2003) Antineoplastic effects of Daphne mucronata: Inhibition of DNA and RNA synthesis. Acta Med Iranica 41: 202-206.

Yadanparast R, Mianabadi M, Abdolmohammadi MH (2003) Anti-tumor activity of Dendrostellera lessertii and the inhibitory effect of one of its purified diterepene ester on wehi-164 cell adhesion. Nat Prod Sci 9: 2.

Yazdanparast R, Sadeghi H (2004) Nucleic acid synthesis in cancerous cells under the effect of gnidilatimonoein from Daphne mucronata. Life Sci 74: 1869-1876.

Yoshida M, Feng W, Saijo N, Ikekawa T (1996) Antitumor activity of daphnane-type diterepene gnidimacrin isolated from Stellera chamaejasme. Int J Cancer 66: 268273. 